\title{
Infiltrating Lipoma
}

National Cancer Institute

\section{Source}

National Cancer Institute. Infiltrating Lipoma. NCI Thesaurus. Code C7451.

A benign tumor, composed of lobules of mature adipocytes, that penetrates the surrounding tissue from which it arises. There is usually a higher local recurrence rate when compared with non-infiltrating lipomas. 